\title{
Two Cases of Night Fever Treated with Acupuncture on Young-gol and Dae-back: Considered from Meridian and Collateral Aspects
}

\author{
Na Young Jo \\ Department of Acupuncture \& Moxibustion Medicine, Je-Cheon Hospital of \\ Traditional Korean Medicine, Semyung University

\section{영골 · 대백혈 자침을 통한 야간 발열 환자 치험 2례} \\ 조나영
}

세명대학교 제천한방병원 침구의학과

\begin{abstract}
Objectives : The purpose of this study is to study the effects of acupuncture on Young-gol and Dae-back on night fever and investigate the meridian and collateral aspects of Dong-Si acupuncture through cases of night fever due to Yin deficiency. Methods : Patients have received acupuncture on both sides(Young-gol and Dae-back) at $10 \mathrm{pm}$. The acupuncture treatment lasted for 15 minutes. Body temperature, pulse, and Numeric Rating Scale(NRS) scores for dryness of mouth were measured for the evaluation. Results : Both patients reported symptomatic reduction including night fever, pulse rate, NRS about dry mouth following the described treatments. The night fever disappeared after acupuncture treatment. The mean of pulse rate changed from 82.6 to 74.8(case 1), from 83.5 to 74.3(case 2). The mean of NRS changed from 4.2 to 1.7(case 1), from 3.3 to 2.4 (case 2). Conclusions : In both cases, acupuncture was effective in relieving night fever symptoms. This can be considered from meridian and collateral aspects and the Korean medicine physiological perspective. In the future, systematic and diverse studies related to this will be needed.
\end{abstract}

Key words : Dong-Si acupuncture, Yin deficiency, night fever, young-gol, Dae-back, Korean medicine

\section{Introduction}

Fever is a state in which the body temperature is higher than the normal range and is often associated with acute or chronic disease. Thus, fever is an important indicator of disease occurrence ${ }^{1)}$. In Korean medicine, fever is mainly caused by external contraction(外感) and internal damage(內 傷). The disharmony between Yin(陰) and Yang(陽) is also the cause of heat ${ }^{2}$. Yin deficiency(陰虛) is a kind of such disharmony.

Symptoms of Yin deficiency are caused by the lack of Yin and the failure to control the Yang. The main symptoms of Yin deficiency are fever, malar flush, mild knee pain, and night sweats. The fever from Yin deficiency appears at a certain time in the night. The fever disappears in the daytime and appears again at night. Yin deficiency is also charac-

Received August 23, 2017, Revised September 14, 2017, Accepted September 15, 2017

Corresponding author: Na Young Jo

Department of Acupuncture \& Moxibustion Medicine, Je-Cheon Hospital of Traditional Korean Medicine, Semyung University, Semyung-ro 66,

Sinwoul-dong, Jecheon 27136, Korea

Tel: +82-43-649-1816, Fax: +82-43-645-1382, E-mail: cswcny2@hanmail.net

(c) This is an open access article distributed under the terms of the Creative Commons Attribution Non-Commercial License (http://creativecommons.org/licenses/ by-nc/4.0) which permits unrestricted non-commercial use, distribution, and reproduction in any medium, provided the original work is properly cited. 
terized by low fever ${ }^{3}$.

In Korean medicine, Yin deficiency is treated with acupuncture, herbal medicine, moxibustion, and pharmacopuncture $^{4}$. Previous studies on fever and Korean medicine have mainly focused on herbal medicine ${ }^{5,6}$. Song's study concerns fever due to Qi deficiency(氣虛) ${ }^{5}$. Additionally, Lee's study concerns fever due to external contraction ${ }^{6}$. As a result of reviewing previous studies, it has been concluded that research on fever due to Yin deficiency is very rare.

We treated two Yin deficiency patients. The patients showed typical symptoms of Yin deficiency, such as night fever and malar flush. Dong-Si acupuncture is a type of acupuncture treatment used in Korean medicine that is experience-based ${ }^{7}$. Based on clinical experience and the meridian and collateral aspects, we thought that acupuncture on Young-gol and Dae-back would be effective in fever due to Yin deficiency. Therefore, we used acupuncture on Young-gol and Dae-back treatment for fever due to Yin deficiency. As a result, acupuncture treatment was effective in treating fever from Yin deficiency. We report the cases in the following.

\section{Subjects and Methods}

\section{Subjects}

The study was conducted on patients admitted to the hospital of traditional Korean medicine at semyung University. The subjects were two male patients. They were in their late 70s and experiencing symptoms of Yin deficiency. The purpose of the study, procedures, and adverse reactions were sufficiently explained to the participants, and they both agreed to voluntarily participate.

\section{Method}

1) Acupuncture Treatment Method: Young-gol(靈骨) is located at the contact point between the first and second metacarpal bones. Dae-back(大白) is located at the digital radialis part of the second metacarpal bone ${ }^{7}$. The acupuncture treatment employed disposable, stainless-steel filiform needles $(0.30 \times 40 \mathrm{~mm})$ from Dongbang Acupuncture, Inc. Patients received acupuncture on both sides(Young-gol and Dae-back) at $10 \mathrm{pm}$. The acupuncture treatment lasted for 15 minutes.

2) Diagnosis of Yin Deficiency: Previous studies have been used to diagnose Yin deficiency. The criteria for diagnosing Yin deficiency in Kang' $s^{8)}$ and Kang' $s^{9)}$ studies are dryness of mouth, reddened tongue, dryness of tongue, short and rapid pulse, afternoon or night fever, malar flush, and mirror-like tongue. The most significant criteria are dryness of mouth, afternoon or night fever, short and rapid pulse, and mirror-like tongue. Patients were diagnosed with Yin deficiency according to the diagnostic criteria.

3) Assessment Method of Effect: Three items were measured for the evaluation: body temperature, pulse, and the Numeric Rating Scale(NRS) for mouth dryness. This has been a significant item for diagnosing colds in previous studies $^{8,9)}$.

(1) Body temperature: Body temperature was checked regularly six times a day( $6 \mathrm{am}, 10 \mathrm{am}, 2 \mathrm{pm}, 6 \mathrm{pm}, 10 \mathrm{pm}$, and $2 \mathrm{am}$ ). If the body temperature was higher than normal, it was checked again after one hour.

(2) Pulse: Pulse was measured together when measuring body temperature. The pulse was the average of three measurements.

(3) NRS for dryness of mouth: The discomfort from dryness of mouth was measured using the NRS. Measurements were made at $10 \mathrm{pm}$.

\section{Cases}

\section{Case 1}

1) Name: Han $\bigcirc \bigcirc$

2) Sex/Age: $M / 78$

3) Chief complaint: Lt. side weakness

4) Additional symptoms: Night fever, malar flush, headache

5) Past medical history: Pulmonary tuberculosis(2002, complete recovery)

๑) Hospitalization period: 11. 15 12. 11. 2012 
7) Family medical history: none

8) White blood cells(WBCs) in blood(Normal: 3.5 $\left.10 \times 10^{3} / \mu 1\right)$ :

$6.2 \times 10^{3} / \mu 1(11.15 .2012)$

$4.9 \times 10^{3} / \mu 1(11.20 .2012)$

$3.9 \times 10^{3} / \mu 1(11.26 .2012)$

$5.2 \times 10^{3} / \mu 1(12.07 .2012)$

The patient received blood tests four times during his hospital stay. The WBC counts were all normal. The blood tests show that fever was not associated with inflammation.

9) Treatment other than acupuncture on Young-gol and Dae-back: He has been receiving acupuncture on both sides, Gokji $\left(\mathrm{L}_{11}\right)$, Joksamni( $\left.\mathrm{ST}_{36}\right)$, Taebaek( $\left.\mathrm{SP}_{3}\right)$, Hyeonjong $\left(\mathrm{GB}_{39}\right)$, and Taechung $\left(\mathrm{LR}_{3}\right)$, once per a day. The meridian points were chosen according to acupuncture textbooks ${ }^{10)}$. Chunghylkangkisan and Sibjeondaebotang were supplied three times a day. These treatments are used to alleviate body weakness, the main symptom mentioned by the patient.

10) Change of Body Temperature: At the time of admission, the patient's temperature was normal $\left(36.5^{\circ} \mathrm{C}\right)$. During the daytime, his body temperature remained within the normal range. However, it rose to $37.2^{\circ} \mathrm{C}$ at $10 \mathrm{pm}$. After consulting, we supplied the patient with fluid(normal saline, 11). On the first day, he was observed without any treatment other than fluid. His body temperature was $37.2^{\circ} \mathrm{C}$ at $11 \mathrm{pm}$ and $37.4^{\circ} \mathrm{C}$ at $2 \mathrm{am}$. It returned to normal $\left(36.6^{\circ} \mathrm{C}\right)$ at $6 \mathrm{am}$. On the second day, his body temperature remained within the normal range during the day. However, it was $37.4^{\circ} \mathrm{C}$ degrees at $10 \mathrm{pm}$.
The patient complained of dryness of mouth, headache, and sleeplessness. We performed a tepid massage and bloodletting therapy(Sybsun points). The fluid continued to be supplied. However, this treatment had little effect. The symptoms reoccurred on several days. On November 20, acupuncture on Young-gol and Dae-back was first used. After one hour of using acupuncture treatment, his body temperature was $37.0^{\circ} \mathrm{C}$. After the treatment, his body temperature dropped by $0.8^{\circ} \mathrm{C}$. After 12 days, night fever symptoms appeared. However, after one hour of using acupuncture treatment, his body temperature became normal. The night fever symptoms disappeared after 12 days of using acupuncture on Young-gol and Dae-back(Fig. 1). The symptoms disappeared, and acupuncture on Young-gol and Dae-back was discontinued. No further night fever symptoms appeared until the patient was discharged.

11) Change of Pulse: At the time of admission, the patient's temperature was slightly higher than normal $(80 / \mathrm{min})$. Before acupuncture on Young-gol and Dae-back is mean pulse rates at 10:00 and 11:00 were 83.8 and 82.6, respectively. During the treatment, his mean pulse rates at 10:00 and 11:00 were 81.7 and 75.6 , respectively. After the treatment, his mean pulse rates at 10:00 and 11:00 were 75.7 and 74.8, respectively. His pulse changed in a similar pattern of fever. The pulse rate also decreased after the fever disappeared(Fig. 2).

12) NRS: Before acupuncture treatment, the mean NRS was 4.2. During the treatment, the mean NRS was 3.2. After the treatment, the mean pulse rate at 10:00 was 1.7. The degree

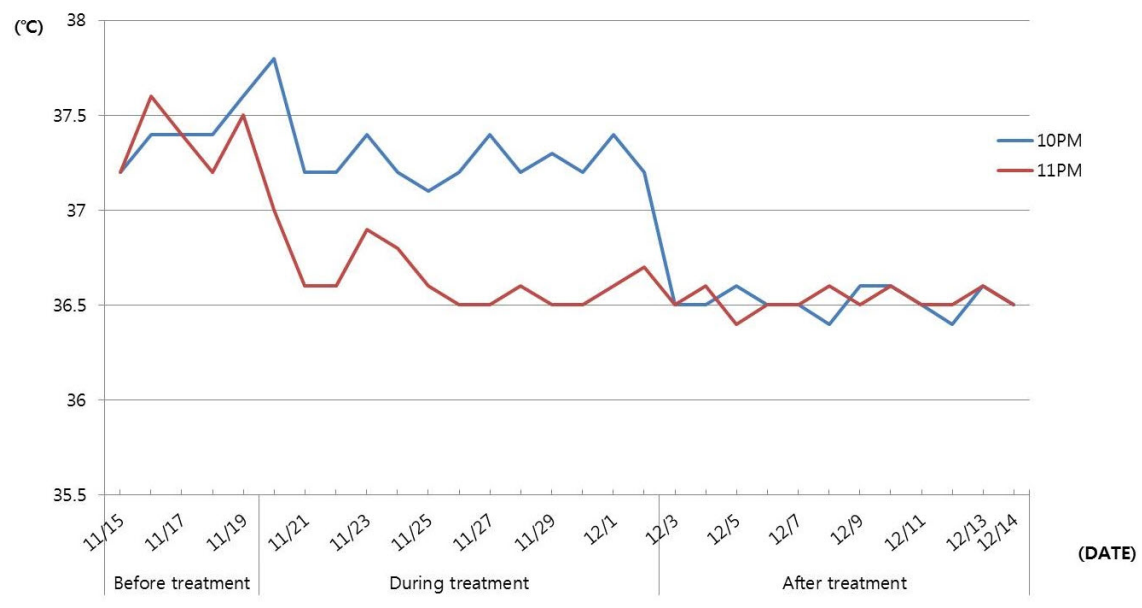

Fig. 1. Changes in body temperature before and after Dong-Si Acupuncture treatment of case 1. Body temperature was checked at $10 \mathrm{pm}$ and $11 \mathrm{pm}$. Start Dong-Si Acupuncture on November 20. Even after starting treatment, night fever occurred from November 20 to December 2. However the fever disappeared after Dong-Si Acupuncture treatment this period. There was no night fever after December 3. 
of mouth dryness of the patient decreased slightly after the disappearance of fever symptoms(Fig. 3).

\section{Case 2}

1) Name: Park $\bigcirc \bigcirc$

2) Sex/Age: $M / 77$

3) Chief complaint: whole body weakness

4) Additional symptoms: Night fever, malar flush

5) Past medical history: Pulmonary tuberculosis(2002, complete recovery)

6) Hospitalization period: 07. 10 08. 08. 2015

7) Family's medical history: none

8) White blood cells(WBC) in blood(Normal: $3.5 \sim 10 \times$ $\left.10^{3} / \mu 1\right)$ :

$5.7 \times 10^{3} / \mu 1(2015$. 07. 10)

\section{$6.5 \times 10^{3} / \mu 1(2015$. 07. 17)}

The patient received two blood tests during his hospital stay. His WBC counts were all normal. The blood tests show that fever was not associated with inflammation.

9) Treatment other than acupuncture on Young-gol and Dae-back: The patient received acupuncture on both sides, Gokji( $\left(\mathrm{LI}_{11}\right)$, Joksamni(ST $\left.\mathrm{S}_{36}\right)$, Taebaek( $\left.\mathrm{SP}_{3}\right)$, Hyeonjong $\left(\mathrm{GB}_{39}\right)$, and Taechung( $\left(\mathrm{LR}_{3}\right)$, once a day. Sibjeondaebotang was supplied three times a day. These treatments are used to alleviate whole body weakness, the main symptom mentioned by the patient.

10) Change of Body Temperature: At the time of admission, the patient's temperature was normal $\left(36.5^{\circ} \mathrm{C}\right)$. During the daytime, his body temperature remained within the normal range. However, it rose to $37.1^{\circ} \mathrm{C}$ at $10 \mathrm{pm}$. After consulting,
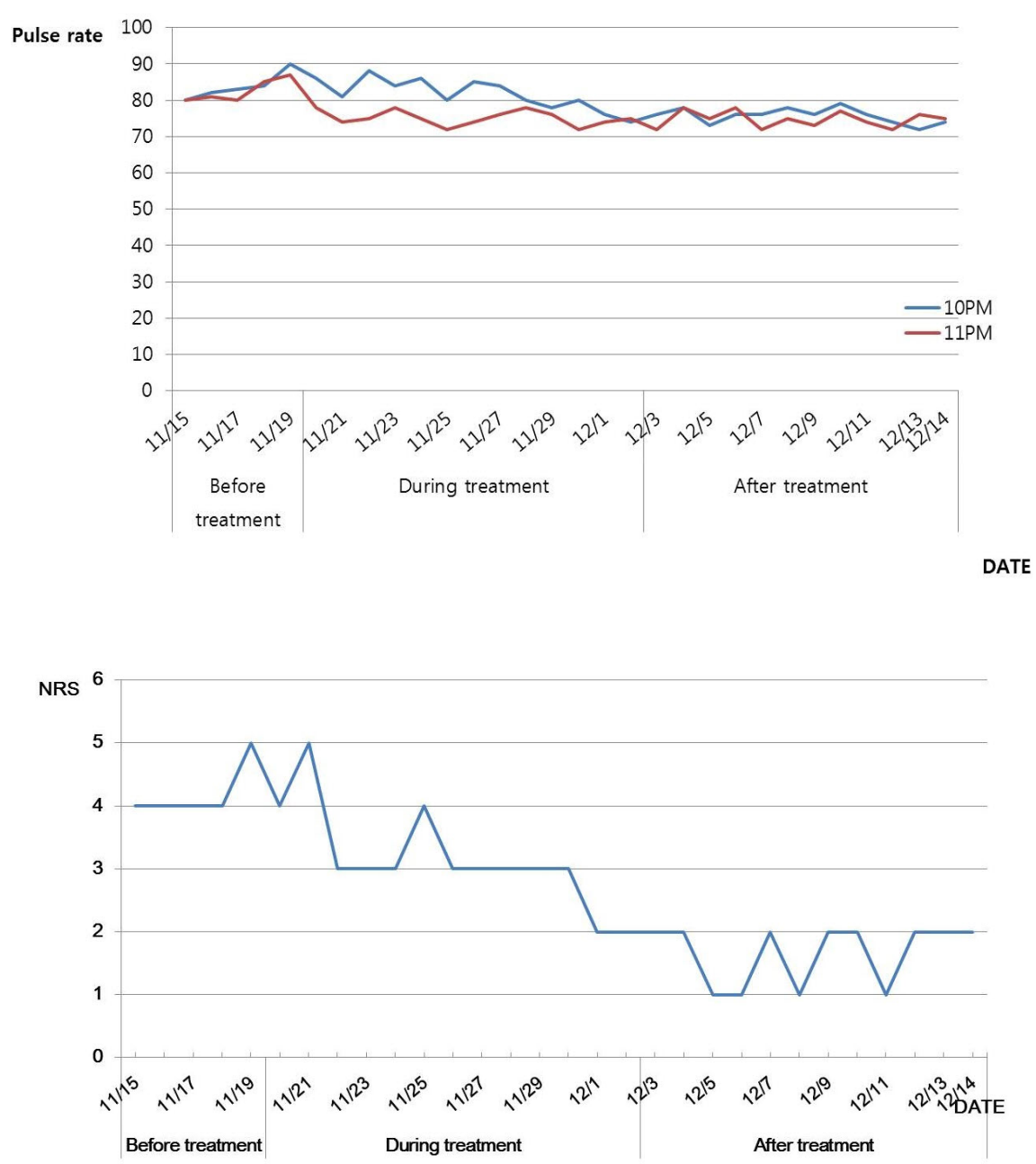

Fig. 2. Changes in pulse rate before and after Dong-Si Acupuncture treatment of case 1.

Pulse rate was checked at $10 \mathrm{pm}$ and $11 \mathrm{pm}$. Start Dong-Si Acupuncture on November 20. There was no night fever after December 3. From November 20 to December 2, patient taken Dong-Si Acupuncture treatment.

Fig. 3. Changes in NRS before and after Dong-Si Acupuncture treatment of case 1.

NRS was checked at $10 \mathrm{pm}$. Start Dong-Si Acupuncture on November 20. There was no night fever after December 3. From November 20 to December 2, patient taken Dong-Si Acupuncture treatment. 
we supplied the patient with fluid(normal saline, $1 \mathrm{~L}$ ). On the first day, he was observed without any treatment other than fluid. The body temperature of the patient was $36.8^{\circ} \mathrm{C}$ at 11 $\mathrm{pm}$. On the second day, his body temperature remained within the normal range during the day. However, it was $37.3^{\circ} \mathrm{C}$ degrees at $10 \mathrm{pm}$. The patient complained of mouth dryness and sleeplessness. We performed a tepid massage, and the fluid continued to be supplied. The symptoms reoccurred on several days. On July 14, acupuncture on Young-gol and Dae-back was first used. After one hour of using the treatment, his body temperature became nor$\operatorname{mal}\left(36.8^{\circ} \mathrm{C}\right)$. After using the treatment, his body temperature dropped by $0.8^{\circ} \mathrm{C}$. After 8 days, night fever symptoms appeared. However, after one hour of using the treatment, his body temperature became normal. On November 23, his temperature was normal. However, he experienced fever at night on November 24th. No night fever was observed after November 25th. The symptoms of night fever completely disappeared after 11 days of using the treatment(Fig. 4). After the symptoms disappeared, the treatment was discontinued. No further night fever symptoms appeared until the patient was discharged.

11) The Change of Pulse: At the time of admission, the patient's temperature was slightly higher than normal(82/min). Before acupuncture on Young-gol and Dae-back, his mean pulse rates at 10:00 and 11:00 were 85.8 and 83.5, respectively. During the treatment, his mean pulse rates at 10:00 and 11:00 were 84.3 and 78.5. After the treatment, the mean pulse rates at 10:00 and 11:00 were 75.7 and 74.3. His pulse changed in a similar pattern of fever. The pulse rate also $\left({ }^{\circ} \mathrm{C}\right)$
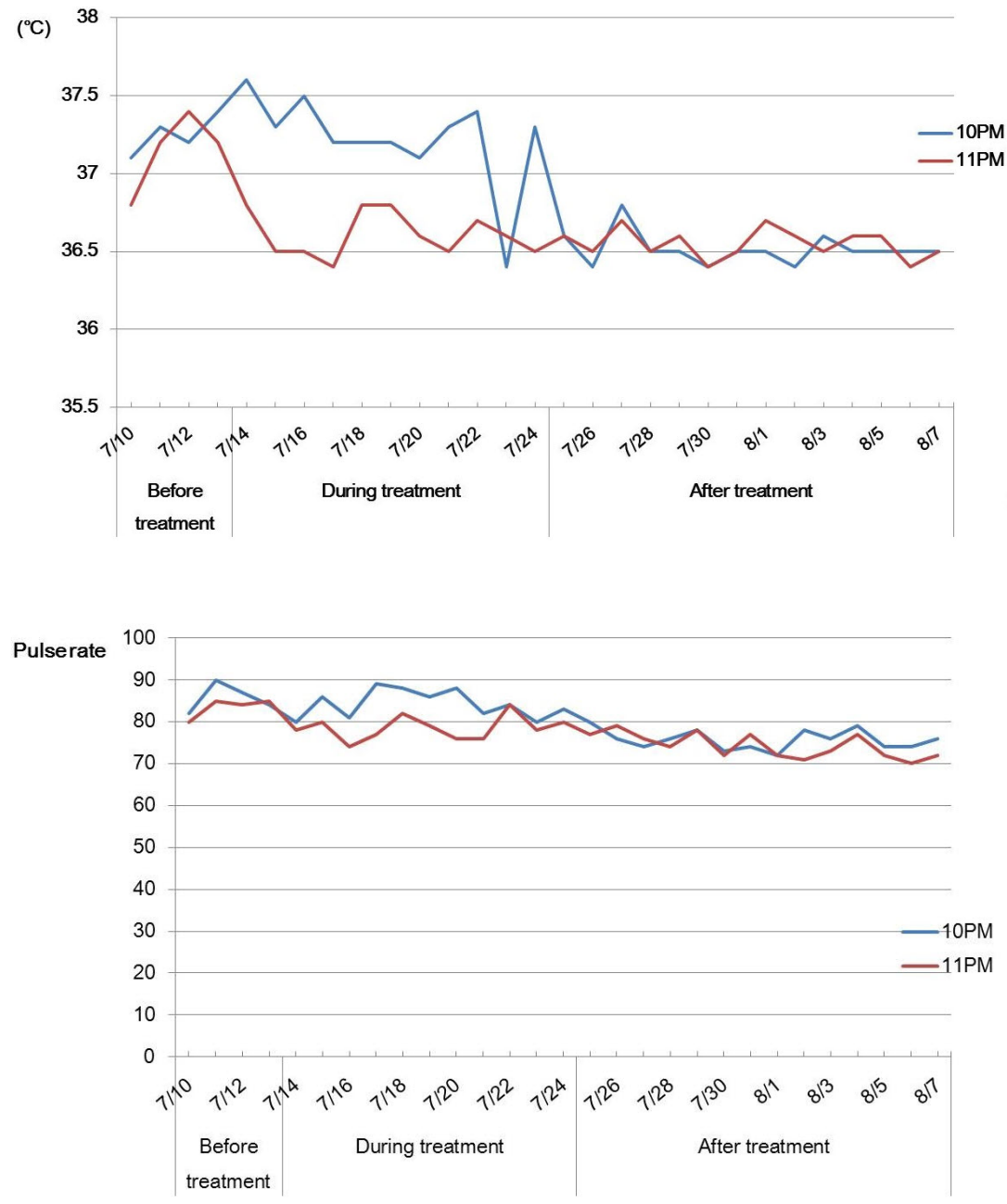

Fig. 4. Changes in body temperature before and after Dong-Si Acupuncture treatment of case 2 .

Body temperature was checked at $10 \mathrm{pm}$ and $11 \mathrm{pm}$. Start Dong-Si Acupuncture on July 14. Even after starting treatment, night fever occurred from November July 14 to July 24 . However the fever disappeared after Dong-Si Acupuncture treatment this period. There was no night fever after July 25 .

Fig. 5. Changes in pulse rate before and after Dong-Si Acupuncture treatment of case 2 .

pulse rate was checked at $10 \mathrm{pm}$ and $11 \mathrm{pm}$. Start Dong-Si Acupuncture on July 14 . There was no night fever after July 25 . From July DATE
14 to July 24, patient taken Dong-Si Acupuncture treatment. 
decreased after the fever disappeared(Fig. 5).

12) NRS: Before acupuncture on Young-gol and Dae-back, the patient's mean NRS was 3.3. During the treatment, his mean NRS was 2.3. After the treatment, his mean pulse rate at 10:00 was 2.4. The degree of mouth dryness of the patient was similar before and after treatment(Fig. 6).

\section{Discussion}

Yin deficiency is a pathological change that causes the deficiency of fire to rise due to lack of Yin. The main symptoms of the deficiency of fire are cherry lips, malar flush, mild knee pain, dryness of mouth, and rapid pulse ${ }^{3)}$.

Dong-Si acupuncture uses approximately 740 meridian points and divides the human body into 12 zones. Young-gol and Dae-back are meridian points on the hand. Young-gol is located at the contact point between the first and second metacarpal bones. Dae-back is located at the digital radialis part of the second metacarpal bone. The two meridian points are mostly used together in treatment. These meridian points have the effects of reducing fever, inflammation, or muscle pain. Therefore, they are mainly used to treat pneumonia, facial palsy, lower back pain, and headache ${ }^{10,11}$.

In both cases, the patients displayed fever symptoms at night and their body temperature returned to the normal range after 1 hour of acupuncture on Young-gol and Dae-back. In Case 1, the night fever disappeared after 13 days of acupuncture treatment. In Case 2, the night fever disappeared after 14 days of acupuncture on Young-gol and Dae-back. In Case 1, the mean pulse rate changed from 81.7 before treatment to 75.2 after treatment. In Case 2, the mean pulse rate changed from 84.3 before treatment to 78.5 after treatment. In Case 1, the mean NRS changed from 4.2 before treatment to 3.2 after treatment. In Case 2, the mean NRS changed from 3.3 before treatment to 2.3 after treatment.

It is also possible that this affected the symptom improvement. However, the fever symptoms did not improve while maintaining the existing therapy. After using the acupuncture on Young-gol and Dae-back, the fever symptoms were significantly improved. Therefore, it can be assumed that acupuncture on Young-gol and Dae-back plays a major role in symptom improvement. As the fever caused by the Yin deficiency went down, the pulse also stabilized.

From the meridian and collateral aspects, we can understand the function of Young-gol and Dae-back. The positions of the two meridian points are included in the area of the large intestine meridian and large intestine meridian sinew. The meridian points belonging to the large intestine meridian are mainly used to treat gastrointestinal diseases or fever ${ }^{10)}$. Among the meridian points of large intestine meridian, Samgan $\left(\mathrm{LI}_{3}\right)$ and Hapgok $\left(\mathrm{LI}_{4}\right)$ are closest to Young-gol and Dae-back. Samgan $\left(\mathrm{L}_{3}\right)$ and Hapgok $\left(\mathrm{L}_{4}\right)$ are efficacious against fever. There has been a study on the effect of acupuncture on face temperature changes. In this study, Hapgok $\left(\mathrm{LL}_{4}\right)$ was selected as a treatment point ${ }^{12}$. There are

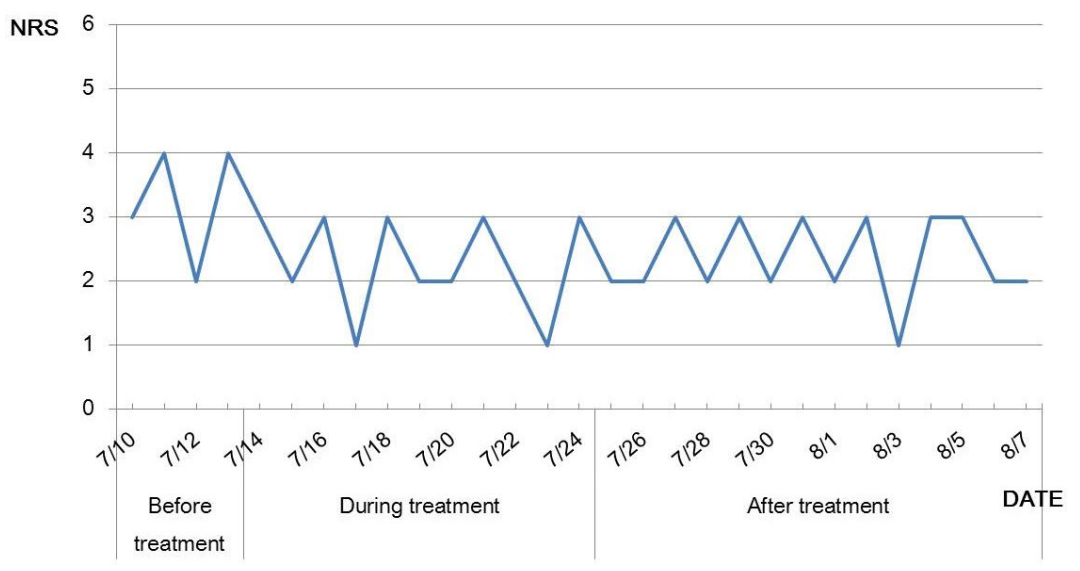

Fig. 6. Changes in NRS before and after Dong-Si Acupuncture treatment of case 2.

NRS was checked at $10 \mathrm{pm}$. Start Dong-Si Acupuncture on July 14. There was no night fever after July 25 . From July 14 to July 24 , patient taken Dong-Si Acupuncture treatment. 
also studies using both Samgan $\left(\mathrm{LI}_{3}\right)$ and Hapgok(LI $\mathrm{LI}_{4}$. In Yun's study ${ }^{13)}$ changes were observed in facial temperature after Samgan $\left(\mathrm{L}_{3}\right)$ and Hapgok $\left(\mathrm{LI}_{4}\right)$ acupuncture treatment. Studies have been continuing to further understanding of the relationship between Samgan $\left(\mathrm{LI}_{3}\right)$ and Hapgok $\left(\mathrm{LI}_{4}\right)$ and body temperature.

From a Korean medicine perspective, the large intestine control the body fluids. Yin deficiency is caused by an imbalance in or lack of body fluids. The large intestine meridian has the effect of mitigating this imbalance, ${ }^{9,14}$. This is one of the reasons why large intestine meridian points are effective in fever due to body fluid imbalance. The positions of the Young-gol and Dae-back meridian points are areas of the large intestine meridian. Furthermore, although the large intestine meridian is most commonly used for excess heat, a previous study ${ }^{15)}$ has shown examples of yin deficiency-induced midday fever. Therefore, it is thought that Young-gol and Dae-back showed a fever effect through a similar mechanism.

This study showed that it is possible to use the Young-gol and Dae-back meridian points for Yin deficiency-induced fever. However, this study has limitations in predicting the effects of the Young-gol and Dae-back meridian points. The number of cases was small for generalization and the research method was not systematic. Thus, further studies on Dong-Si acupuncture and the Young-gol and Dae-back meridian points should be conducted.

\section{References}

1. Compilation Committee of Harrison's Principles of Internal Medicine. Harrison's Principles of Internal Medicine. 18th. Seoul: Jungdam. $2011:$ 31-45.

2. Hong WS. Huang Di Nei Jing. 1st. Seoul: Traditional Culture Research Society. 1992 : 41, 209.

3. Lee BS, Park YB, Kim TH. Korean diagnosis. 7th. Gyeonggi: SungBoSa. 2009: 19, 38.
4. Department of Kidney internal medicine. Kidney internal medicine textbook. 2nd. Seoul: GunJapublisher. 2015 : 42-63.

5. Song KK, Seo YH, Jeon KO, Kwon EH. Two Cases of Fever from Deficiency of Qi. Korean J. Orient. Imt. Med. 2004 ; 25(4) : 410-7.

6. Lee SM, Jung DH, Jung HS. Three Cases of Fever Treated with Chungyoung-tang. Korean J. Physiology \& Pathology. 2001 ; 15(6) : 1025-8.

7. Choi MH. Dong-Si Acupuncture. 1st. Seoul: Iljungsa. 1997 : 9-13, 55-7.

8. Kang KW, Go HY, Kang BK et al. Study of The Diagnostic Indicators of Deficiency of Eum Pattern Identification In Stroke Patients. Korean J. Oriental Physiology \& Pathology. 2007 ; 21(6) : 1655-9.

9. Kang BG, Kang BK, Lee JS et al. Study of the Specific Indicators Calculation of Fire-Heat Pattern Identification and Yin Deficiency Pattern Identification in Stroke. Korean J. Physiology \& Pathology. 2008 ; 22(6) : 1368-73.

10. Korean Medicine Univ Acupuncture \& Moxibustion and Acupoint Department. The Acupuncture and Moxibustion I. 1st. Seoul : Jipmoondang. 1998: 19-36.

11. Joo HW, Kim SG. How to choose Dong-Si Acupuncture meridian point. 1st. Seoul: Deasungmedical books. 2005 : 82-8.

12. Hong KJ, An SH, Kim JH, Hwang JH, Kim KS, Sohn IC. Effects of Acupuncture at Hap-Kok( $\left.\mathrm{LI}_{4}\right)$ on the Skin Temperature Changes of face divided by 17 area randomly in Man. The acupunt. 2002 ; 19(1) : 24-38.

13. Yun JH, Kim JH, Hwang CY, Lim KS. Effects on the Thermal Change of the Face Follow Electroacupunctyre on Hapkok(LI4), Sangan $\left(\mathrm{LI}_{3}\right)$. The J. of Oriental medical surgery. 1999 ; 12(2) : 222-47.

14. Council of professor of Korean Physiology. Oriental Physiology text book. 1st. Seoul: Jibmundang. $2008: 117-37$.

15. Jang HS, Kim YH, Kim SH, Lee JH, Lee EJ, Song IB et al. A Case Study of a Somatoform Disorder Patient Diagnosed with Soyangin Symptomatic Pattern of 'Yin-Deficiency-Midday-Fever. J. of Sassan Constitutional Medicine. 2008 ; 20(2) : 119-28. 


\section{국문초록}

목적 : 본 연구는 음허로 인한 야간발열 환자 2명에 대한 동씨침의 영골 및 대백혈의 치료효과를 알아보고, 이를 경락학적으로 고찰하는데 목적이 있다. 방법 : 음허로 진단된 2명의 환자를 대상으로 영골 및 대백혈에 침 치료를 시행하고, 15 분 간 유침하였으며, 치료 전 후에 체온과 맥박을 측정하고, 구갈에 관한 NRS를 치료전에 측정하였다. 결과 : 영골 및 대백혈 자침 1 시간 후 체온이 두명의 환자 모두 정상범위로 하강하 였으며, Case 1 의 경우는 영골 및 대백혈 자침치료를 시작한지 13 일후, Case 2 의 경우에는 14 일 후에 야간발열 증상이 소실되었다. $11 \mathrm{pm}$ 에 측정한 맥박수는 Case 1에서 침 치료 시작 전 평균 82.6에서 치료 기간중에는 75.2, 치료 후 74.8로 변화하였고, Case 2에서는 침 치료 시작전 평균 83.5에서 치료 기간 중에는 78.5, 치료 후 74.3으로 변화하였다. NRS는 Case 1에서 치료 전 평균 4.2에서 치료 기간 중에는 3.2 , 치료 후 1.7로 감소하였으나 Case 2에서는 치료 전 평균 3.3에서 치료 기간 중에는 2.3 , 치료 후 2.4 로 변화하였다. 결론 : 두 가지 Case에서 영골 및 대백혈 자침은 발열증상을 완화하는데 효과적이었다. 이는 영골 및 대백혈이 수양명대장경의 경락 및 경근이 분포하는 영역에 위치하고 있기 때문에 수양명대장경의 열성병 치료효과와 대장주진의 생리학적 관점에서 고찰해 볼 수 있으며, 앞으로 이와 관련한 체계적이고 다양한 연구가 필요하리라 사료된다.

Key words : 동씨침, 음허발열, 야간발열, 영골, 대백, 한의학 